\title{
Rencana Kontijensi untuk Tanah Longsor di Desa Kalikuning, Pacitan, Jawa Timur
}

\author{
Tatas, I Putu Artama Wiguna, Machsus, Tri Dani Widyastuti, \\ Mohammad Arif Rohman \\ Pusat Studi Kebumian, Bencana, Perubahan Iklim (PSKBPI), \\ Institut Teknologi Sepuluh Nopember, Surabaya \\ Email: tatas@ce.its.ac.id
}

\begin{abstract}
Contingency plan $(C P)$ is part of the concept of disaster risk management as a mitigation measure in the form of a document as a complement to emergency disaster management plans. In addition, it is a systematic effort that aims to disaster preparedness, such as landslide. On January 2, 2011, landslides occurred in Desa Kalikuning which is about 16 kilometers to the northeast Pacitan City. There were no victims but some houses got damaged. However, according to previous investigations, potential landslides would occur. If the landslide occurred, the possibility of the affected area was in $R T 1,2,3 R W I X$ which is located in the "bowl" of potential landslides. Contingency plans were needed to prepare the possibility of landslides. The method used in this study was Focus Group Discussion (FGD) which involved stakeholders. Based on the results of FGD, to establish the document of CP involved several steps which were the hazard assessment, hazard determination, the determination of scenario, the determination of policy, and the planning of section allocation. The planning of section allocation was divided into management and coordination, evacuation, logistics, healthcare, transportation, communications, and infrastructure. These five factors were performed according to the instructions of Pacitan regent. In addition, there was some gap between the need and availability of resources such as the lack of corpse bags, evacuation equipment, etc while there was excessive availability of medical personnel.
\end{abstract}

Keywords: contingency plans, landslide, Pacitan.

Abstrak

Rencana kontijensi merupakan bagian dari konsep manajemen resiko bencana sebagai upaya mitigasi yang berupa dokumen sebagai pelengkap rencana penanggulangan kedaruratan bencana. Rencana kontijensi merupakan upaya sistematis yang bertujuan untuk kesiapsiagaan bencana, misalnya bencana tanah longsor. Pada tanggal 2 Januari 2011, longsor terjadi di Desa Kalikuning yang berjarak sekitar 16 kilometer ke arah timur laut Pacitan Kota. Tidak ada korban pada waktu itu kecuali beberapa rumah mengalami kerusakan. Namun, menurut penyelidikan sebelumnya, longsor berpotensi akan terjadi. Jika tanah longsor terjadi, kemungkinan daerah yang terkena adalah di Rukun Tetangga (RT) 1, 2, 3 dalam Rukun Warga (RW) IX yang terletak di dalam "mangkuk" longsor yang potensial terjadi. Untuk menyiapkan segala sesuatu apabila hal tersebut benar terjadi maka perlu dilakukan penyusunan rencana kontijensi. Metode yang digunakan adalah dengan Focus Group Dicussion (FGD). Kegiatan tersebut dilakukan dengan melibatkan beberapa stakeholder, yaitu perwakilan Komunitas di Kalikuning, Lembaga Swadaya Masyarakat (LSM), dan dinas pemerintah setempat yang terkiat dengan kesehatan, informasi, transportasi, konstruksi, sosial, termasuk lembaga militer. Berdasarkan hasil FGD, dokumen rencana kontingensi didirikan melibatkan beberapa langkah, yaitu penilaian bahaya, penentuan insiden bahaya, penentuan skenario, penentuan kebijakan, dan perencanaan alokasi sektoral. Perencanaan alokasi sektoral dibagi dalam manajemen dan koordinasi, evakuasi, logistik, kesehatan, transportasi, komunikasi, dan infrastruktur. Kelima sektor tersebut bergerak atas instruksi Bupati Pacitan atau yang ditunjuk, dengan koordinasi utama ada pada sektor manajemen dan koordinasi. Selain itu, ada beberapa kesenjangan antara kebutuhan dan ketersediaan sumber daya seperti kurangnya kantong mayat, alat evakuasi, dll. Sedangkan kebutuhan yang telah melebihi kebutuhan adalah terkait dengan jumlah tenaga medis.

Kata kunci: rencana kontinjensi, longsor, Pacitan.

Jurnal APLIKASI: Media Informasi \& Komunikasi Aplikasi Teknik Sipil Terkini Halaman 27 


\section{Pendahuluan}

Desa Kalikuning, Kabupaten Pacitan mengalami longsor pada tanggal 2 Januari 2011. Longsor terjadi di Dusun Sono. Desa Kalikuning yang berada di Kecamatan Tulakan ini berlokasi di timur laut Pacitan Kota (lihat Gambar 1). Posisi astronomis Dusun Sono ada pada kisaran koordinat UTM 524522 meter timur; 9101831 meter selatan. Perjalanan ke Dusun Sono dapat ditempuh melalui perjalanan darat dengan durasi antara satu sampai dengan dua jam perjalanan dari pusat pemerintahan, Kabupaten Pacitan. Sedangkan jarak horisontal antara kedua lokasi tersebut sekitar 16 Km (Tatas, dkk. 2011).

Gambar 2 menunjukkan Peta Situasi Dusun Sono, lokasi utama tanah longsor. Warga memberikan informasi bahwa retakan telah terjadi pada pertengahan Tahun 2010 yang berupa retakan tanah yang memanjang. Tanggal 30 Desember 2010 terjadi hujan deras. Masyarakat sepertinya telah memahami potensi yang mungkin terjadi akibat peristiwa alam tersebut sehingga masyarakat memutuskan mengungsi pada hari itu. Selang dua hari, Tanggal 2 Januari 2011, terjadi longsor pada bukit di sisi selatan Telaga Sono (Tatas, dkk. 2011).

Longsor yang merupakan gerakan massa tanah, sering terjadi pada lereng alami maupun lereng buatan. Fenomena tersebut merupakan usaha dari lapisan permukaan tanah untuk mencari keseimbangan baru. Hal tersebut akibat adanya gangguan yang menyebabkan terjadinya pengurangan kuat geser serta peningkatan tegangan geser tanah. Selain kondisi topografi yang miring, pemicu lainnya adalah air hujan dan gempa bumi (Priyono, 2008). Pengurangan kuat geser tanah di alam karena kondisi geologi yaitu jenis dan tekstur (komposisi) tanah pembentuk lereng. Kondisi geologi tersebut berupa sensivitas sifat-sifat tanah lempung karena adanya lapisan tanah shale, loose, pasir lepas, dan bahan organik (Suryolelono K.B, 2002).

Pada konsep penanggulangan bencana, salah satu bentuknya adalah manajemen risiko bencana. Pada tahap tersebut, diupayakan bila terjadi peristiwa bencana, kerusakan, dan kerugian dengan skala dampak yang cukup besar dapat dihindari, atau diminimalisir. Semua potensi risiko kejadian bencana di suatu wilayah, diidentifikasi dan kemudian diukur tingkatannya dengan metode analisis risiko. Berdasarkan tingkat risiko dari masing-masing kejadian, dapat dilakukan upaya untuk mengurangi ancaman dan dampak yang akan ditimbulkan, yang sering disebut sebagai upaya mitigasi.

Salah satu bentuk upaya mitigasi tersebut berupa rencana kesiapsiagaan untuk mengantisipasi datangnya bencana yang disebut dengan Rencana Kontijensi (Renkon). Rencana Kontinjensi diperlukan sebagai acuan apabila sebuah kejadian bencana betul-betul terjadi. Rencana ini menjelaskan tentang siapa saja yang harus terlibat dan tugas atau peranan setiap komponen manakala terjadi peristiwa bencana. 


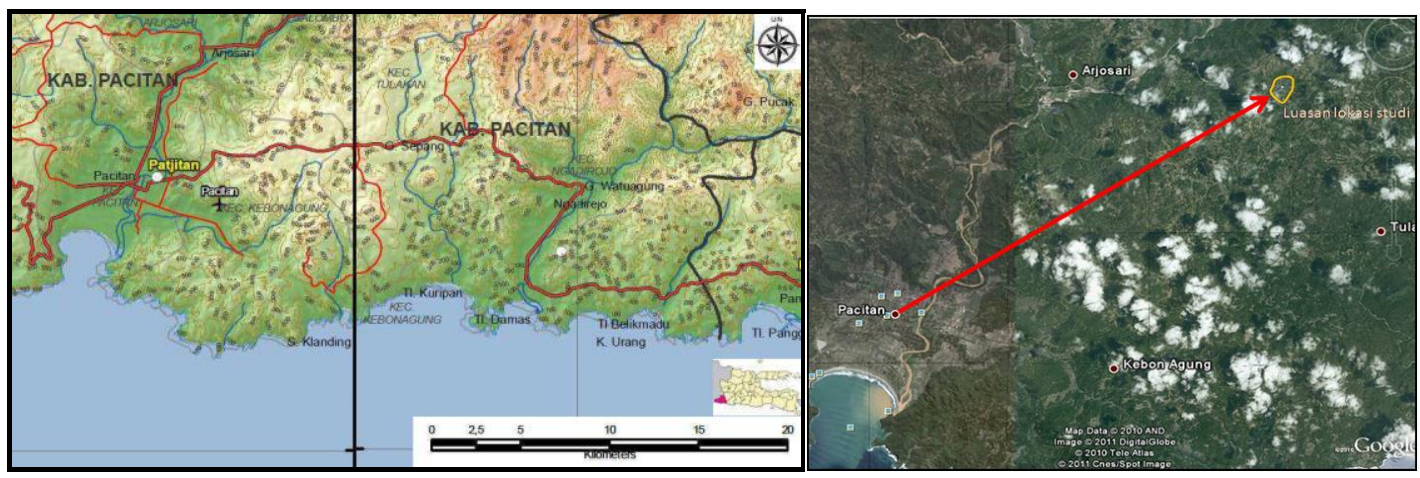

Gambar 1. Posisi lokasi studi dan perkiraan luasan longsor

Dalam siklus perencanaan dan penanggulangan bencana, rencana kontinjensi ini masuk dalam fase kesiapsiagaan menghadapi datangnya saat bencana. Secara lengkap Konsep Perencanaan dan Penanggulangan Bencana yang direkomendasikan oleh Badan Nasional Penanggulangan Bencana (BNPB) ini ditunjukkan dalam Gambar 2. Dengan adanya longsor di Desa Kalikuning pada 12 Januari 2011, yang memberi bekas akan adanya longsor susulan berupa garis-garis amblesan tanah, maka perlu disusun Rencana Kontijensi untuk menanggulangi potensi bencana tersebut.

Terkait dengan kondisi tersebut, kajian ini dimaksudkan untuk menyusun Rencana Kontinjensi untuk menghadapi bencana tanah longsor di Desa Kalikuning, Kecamatan Tulakan, Kabupaten Pacitan. Diharapkan melalui rencana yang sudah dibuat ini seluruh stakeholder yang terkait dapat mengetahui dan ikut terlibat secara aktif dalam menyiapkan kesiapsiagaan menghadapi bencana yang mungkin terjadi. Rencana kontijensi tersebut disusun sebelum kedaruratan/kejadian bencana, dengan sifat rencana yang terukur. Cakupan kegiatan dalam dokumen rencana kontijensi adalah spesifik yang dititikberatkan pada kegiatan untuk menghadapi keadaan darurat. Dalam dokumen rencana kontijensi, hanya memuat satu jenis ancaman bencana (single hazard) dengan pelaku yang terlibat sebatas pada ancaman tersebut (Triutomo, dkk. 2011).

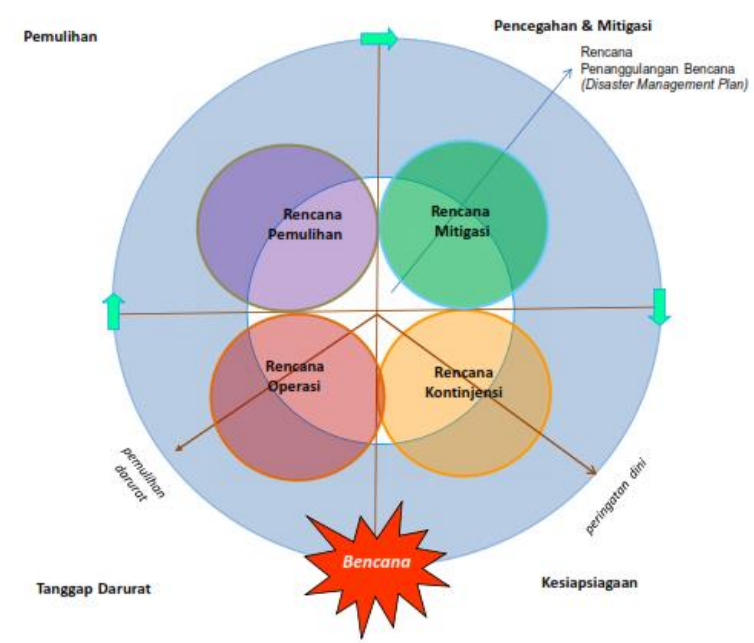

Gambar 2. Jenis perencanaan dalam penanggulangan bencana (Triutomo, dkk. 2011). 


\section{Metodologi}

Metode yang digunakan untuk menyusun Rencana Kontijensi (Renkon) dapat dilihat pada Gambar 3. Tahapan penyusunan meliputi penilaian bahaya, penentuan kejadian, pengembangan skenario, penetapan kebijakan strategi. Selanjutnya melakukan analisis

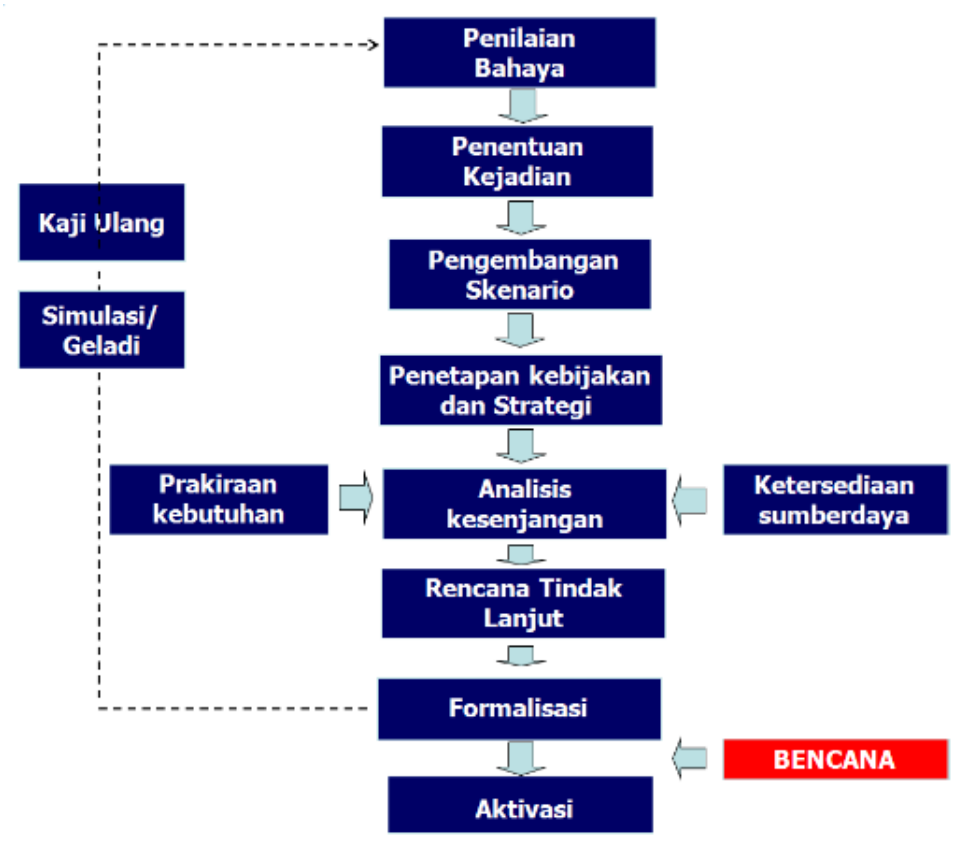

Gambar 3. Tahapan Penyusunan Rencana Kontijensi (Triutomo, dkk. 2011).

kesenjangan dengan membandingkan perkiraan kebutuhan apabila bencana yang dimaksud terjadi dengan ketersediaan sumberdaya yang dimiliki dan pada tahap akhir disusun rencana tindak lanjut. Tahapan-tahapan tersebut terdapat pada dokumen Renkon. Setelah dokumen berhasil disusun, maka tahapan selanjutnya adalah melakukan proses formalisasi yaitu suatu proses penetapan keabsahan dokumen Renkon.

Analisis risiko dilakukan terhadap satu jenis ancaman yang sudah diidentifikasi sebelumnya, yaitu ancaman tanah longsor. Analisis risiko dilakukan dengan menggunakan formula sebagai berikut:

$$
\text { Risiko }=\text { Probabilitas } \mathrm{x} \text { Dampak }
$$

Variabel Probabilitas $($ probability $=\mathrm{P})$ menyatakan kemungkinan atau frekuensi kejadian dari sebuah ancaman bencana. Sedangkan variabel Dampak (Impact = I) menyatakan besarnya dampak atau akibat apabila sebuah bencana terjadi. Analisis risiko secara kualitatif dipakai sebagai pendekatan untuk menentukan tingkat risiko ancaman yang sudah diidentifikasi. Pada analisis risiko ini digunakan lima klasifikasi yang menunjukkan tingkatan/level dari variabel probabilitas dan dampak.

Variabel probabilitas dikategorikan menjadi lima klasifikasi, yaitu pasti, kemungkinan besar, kemungkinan terjadi, kemungkinan kecil, dan kemungkinan sangat kecil sebagaimana dapat dilihat pada Tabel 1, sedangkan 
variabel dampak dikategorikan menjadi lima klasifikasi, yaitu sangat parah, parah, sedang, ringan dan sangat ringan sebagaimana dapat dilihat pada Tabel 2.

Tabel 1. Klasifikasi tingkatan dan kriteria untuk variabel probabilitas (Triutomo, dkk. 2011)

\begin{tabular}{|c|c|c|}
\hline Bobot & $\begin{array}{c}\text { Level } \\
\text { Probabilitas }\end{array}$ & $\begin{array}{c}\text { Penjelasan Kriteria } \\
\text { Probabilitas }\end{array}$ \\
\hline 5 & Pasti & $\begin{array}{l}\text { Hampir dipastikan } \\
80-99 \%\end{array}$ \\
\hline 4 & $\begin{array}{l}\text { Kemungkinan } \\
\text { besar }\end{array}$ & $60-80 \%$ terjadi \\
\hline 3 & $\begin{array}{l}\text { Kemungkinan } \\
\text { terjadi }\end{array}$ & $40-60 \%$ terjadi \\
\hline 2 & $\begin{array}{l}\text { Kemungkinan } \\
\text { Kecil }\end{array}$ & $20-40 \%$ terjadi \\
\hline 1 & $\begin{array}{l}\text { Kemungkian } \\
\text { sangat kecil }\end{array}$ & $0-20 \%$ terjadi \\
\hline
\end{tabular}

Tabel 2. Klasifikasi tingkatan dan kriteria untuk variabel dampak (Triutomo, dkk. 2011)

\begin{tabular}{|c|c|c|}
\hline Bobot & $\begin{array}{l}\text { Level } \\
\text { Dampak }\end{array}$ & $\begin{array}{c}\text { Penjelasan Kriteria } \\
\text { Dampak }\end{array}$ \\
\hline 5 & $\begin{array}{l}\text { Sangat } \\
\text { parah }\end{array}$ & $\begin{array}{l}80-99 \% \text { wilayah } \\
\text { hancur/lumpuh total }\end{array}$ \\
\hline 4 & Parah & $\begin{array}{l}60-80 \% \text { wilayah } \\
\text { hancur }\end{array}$ \\
\hline 3 & Sedang & $\begin{array}{l}40-60 \% \text { wilayah } \\
\text { terkena rusak }\end{array}$ \\
\hline 2 & Ringan & $\begin{array}{l}20-40 \% \text { wilayah } \\
\text { yang rusak }\end{array}$ \\
\hline 1 & $\begin{array}{l}\text { Sangat } \\
\text { Ringan }\end{array}$ & $\begin{array}{l}\text { Kurang dari } 20 \% \\
\text { wilayah rusak }\end{array}$ \\
\hline
\end{tabular}

Sedangkan untuk melakukan analisa risiko digunakan Matriks ProbabilitasDampak sebagaimana dapat dilihat pada Gambar 4. Tabel 2 dipakai sebagai sarana untuk menentukan tingkat risiko yang terjadi dari kombinasi setiap nilai probabilitas dan dampak dari setiap jenis ancaman. Penentuan nilai dari masing-masing cell matriks dilakukan secara sub- yektif, dimana dalam hal ini bobot lebih besar diberikan untuk variabel dampak (impact) dibandingkan dengan probabilitas.

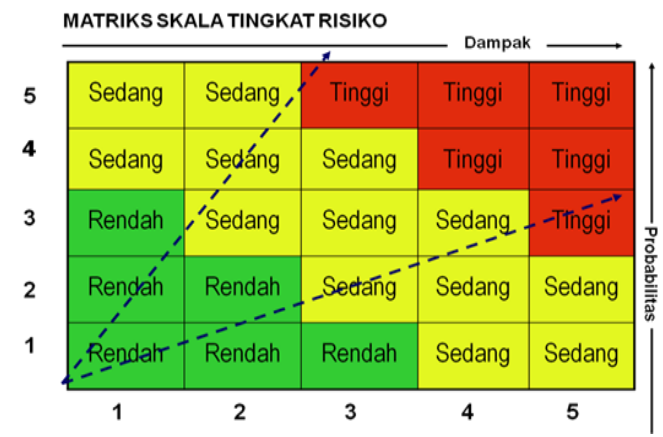

Gambar 4. Analisa Risiko dengan Metode Matriks Probabilitas-Dampak (Triutomo, dkk. 2011)

Dari Gambar 4 dapat dijelaskan bahwa bila probabilitas kejadian adalah kemungkinan sangat kecil dan dampak kejadian adalah sangat ringan, maka tingkat risiko adalah rendah. Bila probabilitas kejadian adalah pasti dan dampak kejadian adalah sangat parah, maka tingkat risiko adalah tinggi. Bila probabilitas kejadian adalah kemungkinan besar dan dampak kejadian adalah ringan, maka tingkat risiko adalah sedang.

Aspek yang terkena dampak bencana dapat dikategorikan menjadi 5, yaitu aspek penduduk, sarana, dan prasarana, ekonomi, pemerintahan dan lingkungan (Triutomo, dkk. 2011). Hal-hal yang perlu dipertimbangkan dalam pengukuran dampak tersebut adalah:

a. Dampak pada penduduk dapat berupa kematian, cidera, hilang, pengungsian, dll. Sebelum melakukan perhitungan dampak tersebut perlu diperkirakan jumlah dan komposisi 
penduduk yang terancam berdasarkan worst scenario.

b. Dampak pada aspek sarana dan prasarana dapat berupa kerusakan jalan, jembatan, instalasi air, listrik maupun rumah penduduk.

c. Dampak pada aspek ekonomi dapat berupa kerusakan pasar, gagal panen, terganggunya perekonomian, perdagangan, dan transportasi.

d. Dampak pada aspek pemerintah dapat berupa kerusakan dokumen/arsip, peralatan kantor, dan bangunan pemerintahan, serta jalannya proses pemerintahan.

e. Dampak pada aspek lingkungan dapat berupa rusaknya kelestarian alam, obyek wisata, dan pencemaran lingkungan.

Sebelum melakukan pengukuran dampak perlu diperkirakan sebaran atau luasan daerah terdampak sehingga perkiraan jumlah penduduk dan daerah terancam dapat diperkirakan dengan lebih tepat.

Selanjutnya pada Tahap Analisis Kesenjangan, salah satu metode yang dapat digunakan adalah dengan melakukan Focus Group Discussion (FGD). Metode ini dipilih karena Dokumen Renkon harus disusun secara bersama-sama oleh para stakeholder yang multi sektor yang memiliki peran dalam penanggulangan bencana. FGD yang dilakukan dengan mengundang para pemangku jabatan yang dapat dilibatkan bila bencana tersebut terjadi. Para pemangku kepentingan tersebut dapat dari instansi pemerintah, Lembaga Swadaya Ma- syarakat, Perkumpulan Sosial, dan tokoh masyarakat setempat.

\section{Hasil dan Pembahasan}

Penilaian Bahaya

Bencana tanah longsor sudah pernah terjadi dan tidak menutup kemungkinan akan terjadi lagi pada lokasi yang sama. Kejadian ini dapat dijadikan acuan dalam penentuan ancaman bencana serupa di masa mendatang. Dengan demikian dapat diidentifikasi bahwa ancaman yang berisiko tinggi dan yang paling mungkin terjadi adalah tanah longsor pada lokasi eksisting.

Longsor tersebut diiringi dengan suara yang bergemuruh. Akibat longsor, Sungai Sono saat itu tertutup material longsor, dan terbentuklah tampungan kecil selama beberapa hari. Di beberapa tempat lain, juga mengalami retakan dan amblesan (Gambar 5a dan 5b). Retakan dan amblesan ada di permukiman warga, jalan akses dan sekolah. Luasan longsor yang telah terjadi pada Tanggal 2 Januari 2011 adalah 12.000 meter persegi (asumsi adalah jarak horisontal pada gambar (Tatas, dkk. 2011).

Secara khusus untuk faktor dampak, penilaian dilakukan terhadap beberapa faktor dampak yang meliputi dampak terhadap manusia, dampak terhadap infrastruktur/sarana prasarana, dampak terhadap lingkungan, dampak terhadap ekonomi, dampak terhadap pemerintah (Triutomo, dkk. 2011). Selanjutnya dilakukan penilaian detail khusus untuk jenis ancaman bahaya tersebut. 


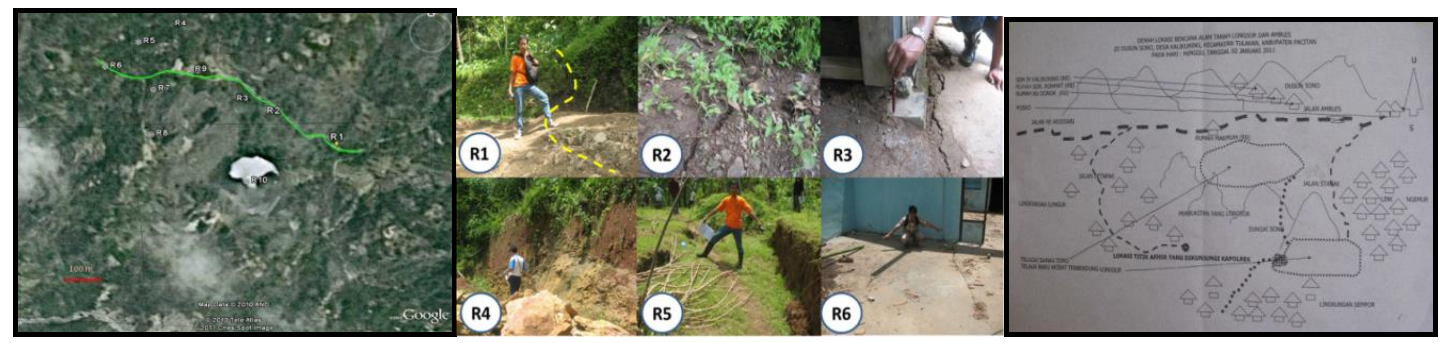

Gambar 5. Gambaran umum longsor di Desa Tulakan dan Potensi Longsor Lanjutan (Tatas, dkk. 2011)

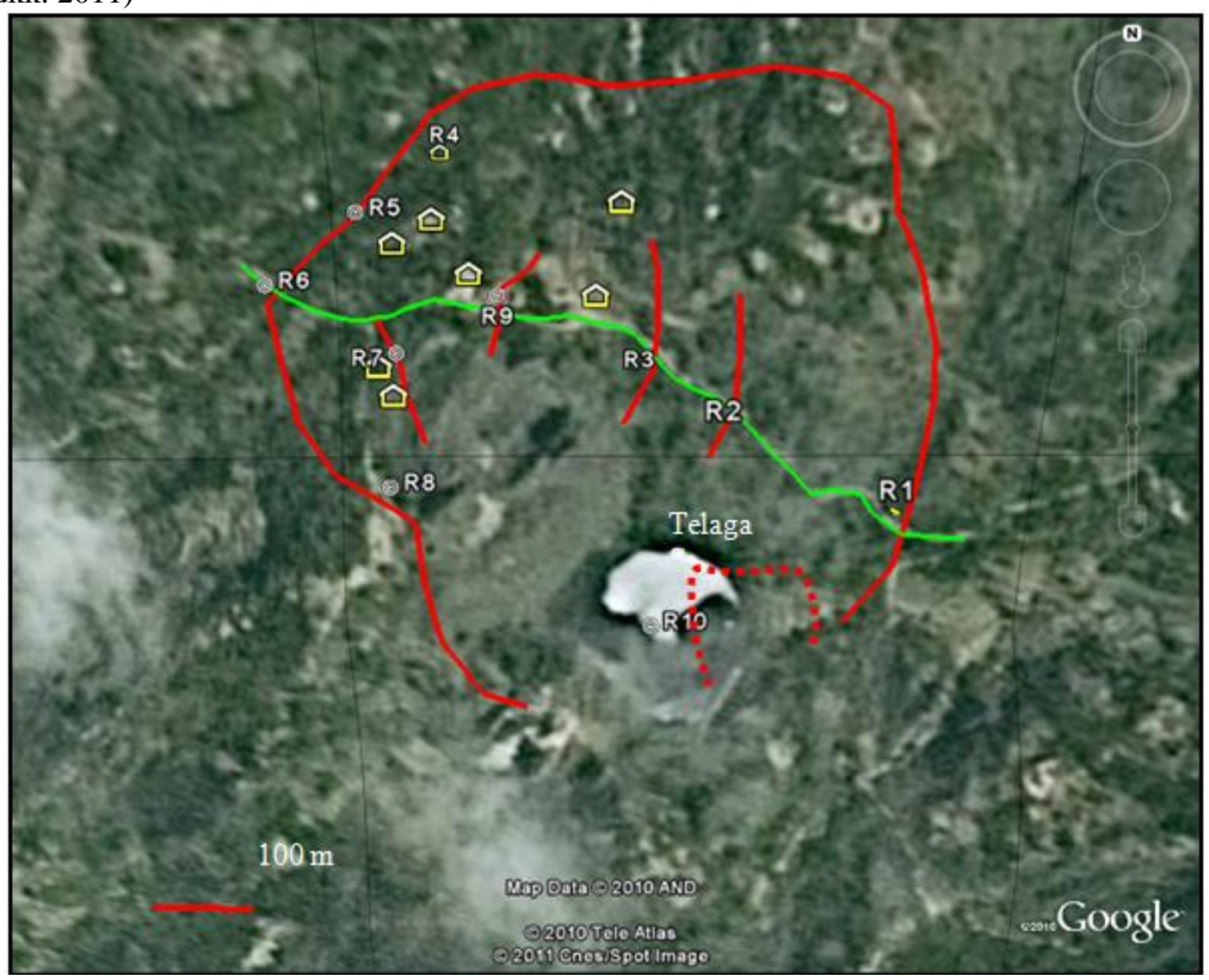

Gambar 6. Prakiraan luasan longsor yang kemungkinan akan terjadi (garis sambung) dan longsor yang telah terjadi, garis putus-putus (Pusat Studi Kebumian dan Bencana, 2012)

Sebelum dilakukan penilaian deteil terlebih dahulu dilakukan pendalaman terhadap kedua jenis ancaman tersebut. Pendalaman ini dimaksudkan agar terdapat kesamaan persepsi terhadap pengertian dan cakupan serta upaya mitigasi yang telah dilakukan terhadap keduanya. Berdasarkan hasil penilaian detail diperoleh bahwa jenis ancaman tanah longsor dinilai memiliki risiko lebih tinggi dibanding jenis ancaman lainnya, misalkan kebakaran hutan, tsunami, dan lain-lain. Satu dokumen Renkon memuat satu jenis bencana. Sedangkan jenis bencana yang lain juga memiliki dokumen Renkon tersendiri. Oleh karena itu, tanah longsor dipilih sebagai jenis ancaman yang paling tinggi atau diprioritaskan. Tahapan selanjutnya adalah dilakukan pengembangan skenario kejadian berdasarkan ancaman terpilih.

$\underline{\text { Penentuan Kejadian }}$ 
Mengingat hanya ada satu jenis ancaman yang sangat berisiko tinggi, maka dalam penentuan risiko dapat langsung ditetapkan tanah longsor sebagai prioritas utama kejadian yang harus ditanggulangi.

Tabel 3. Penentuan Skala Probabilitas dan Dampak

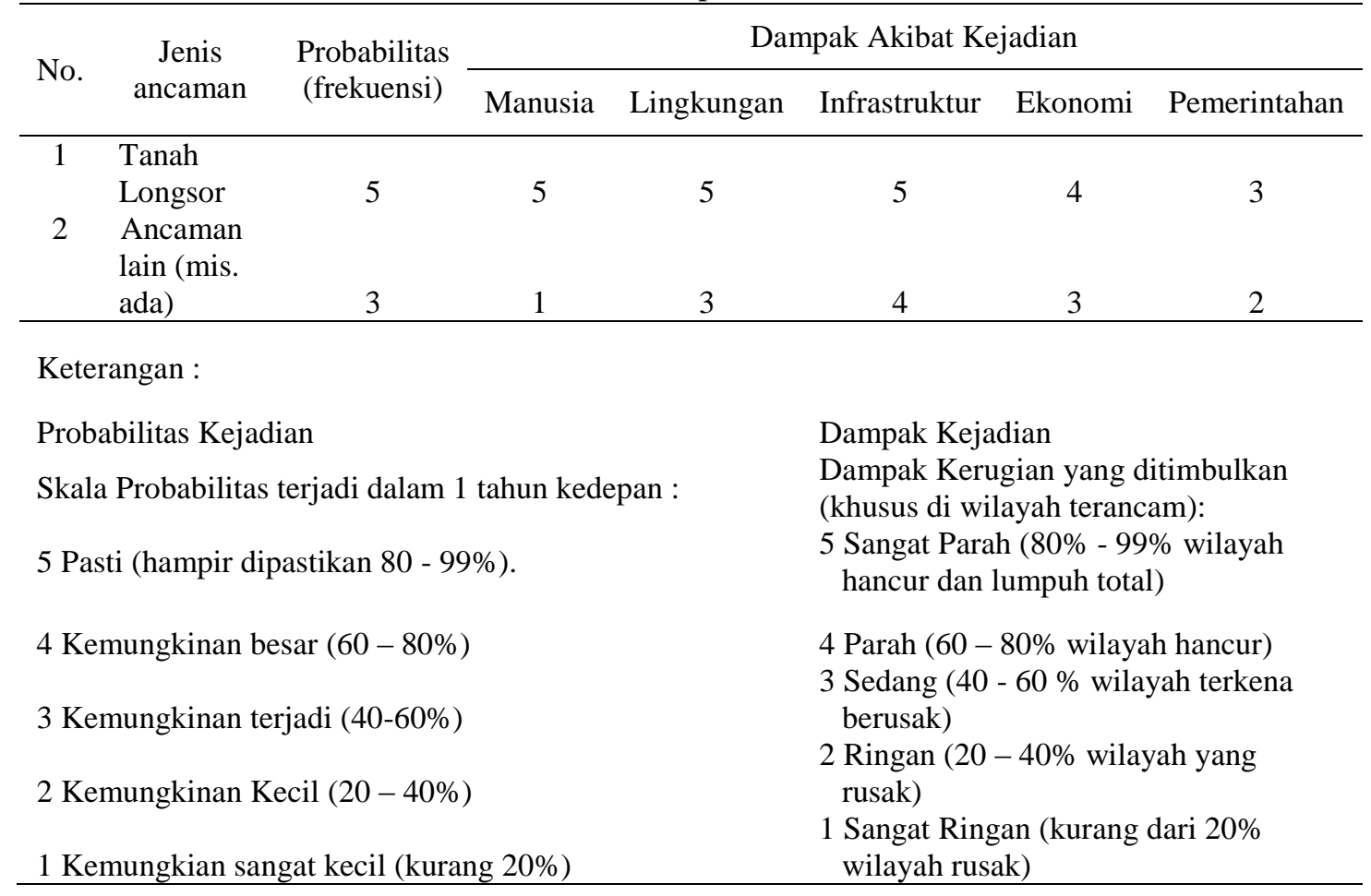

Penentuan risiko ini dapat diperkuat dengan adanya kesepakatan bersama dengan stakeholder maupun dengan instansi terkait atau lintas sektoral secara bersama-sama. Tahapan selanjutnya adalah dilakukan pengembangan skenario kejadian berdasarkan ancaman terpilih.

Berdasarkan hasil penilaian bahaya, diketahui bahwa jenis risiko yang paling tinggi adalah kejadian tanah longsor (Tatas, 2011). Beberapa kejadian yang perlu dipertimbangkan sebagai dasar penyusunan skenario adalah:

1. Waktu kejadian. Waktu kejadian tanah longsor ini akan menentukan bentuk respon yang diberikan. Waktu kejadian malam hari berpotensi menimbulkan jumlah korban yang lebih banyak di permukiman, karena para penghuninya sedang tertidur lelap. sedangkan pagi, siang, atau sore kemungkinan jumlah korbannya lebih sedikit, karena para peghuninya sedang pergi keluar rumah untuk berbagai keperluan. Seperti yang telah terjadi, waktu kejadian biasanya terjadi di malam hari yang diawali dengan curah hujan tinggi selama beberapa hari sebelumnya.

2. Lokasi kejadian: Kemungkinan terjadi tanah longsor tetap pada lokasi eksisting (Gambar 6).

3. Intensitas: Kejadian tanah longsor ini bisa lebih dari satu kali, sangat dipe- 
ngaruhi oleh kondisi intensitas hujan dan kondisi kemiringan lereng di lokasi kejadian.

4. Lama Kejadian: Pada tanah longsor waktunya bisa sangat singkat yaitu hanya hitungan menit atau kurang dari satu jam.

5. Area yang terdampak: Longsoran tanah dapat menimbulkan risiko rusak atau hancurnya bangunan atau bendabenda lain yang berada diatas permukaan tanah yang mengalami longsor. Jadi area terdampak nya bisa meliputi: penduduk, permukiman, persawahan, infrastruktur, dll. Kondisi permukiman yang mungkin terkena dampak dari longsorang tanah dapat dilikat pada sketsa seperti pada Gambar 5 dan 6 .

6. Hal-hal lain yang berpengaruh: Halhal ini yang sangat berpengaruh terhadap timbulnya kejadian tanah longsor ini diantaranya: intensitas hujan yang lebat dalam kurun waktu yang cukup lama, kondisi kemiringan lereng, gundulnya pohon atau hutan pada lereng, dan lain-lain.

Pengembangan Skenario

Untuk dapat membuat rencana pengembangan skenario kejadian, maka perlu diidentifikasi masyarakat (data demografi penduduk) dan daerah yang terancam berdasarkan peta wilayah, sehingga besaran atau luasan dampak yang diakibatkannya dapat diprediksi dengan tepat.

Berdasarkan hasil diskusi dengan para pakar dan stakeholder selama FGD berlangsung, disepakati bahwa pengembangan skenario kejadiannya adalah "Tanah longsor terjadi pada malam hari sekitar pukul 24.00 di lokasi eksisting dengan intensitas satu kali kejadian yang lamanya 5 (lima) menit, sedangkan area yang terdampak adalah kawasan permukiman penduduk di satu Dusun Sono" (Pusat Studi Kebumian dan Bencana, 2012). Lokasi dan area dampak dapat dilihat pada Gambar 6.

Berdasarkan Gambar 6, potensi longsor lanjutan diperkirakan seluas 250.000 meter persegi (Tatas, dkk. 2011). Longsor pada Tanggal 2 Januari 2011 tersebut tidak menimbulkan korban jiwa. Namun potensi longsor selanjutnya berada di jalan akses, sekolah serta permukiman warga Dusun Sono. Kemungkinan longsor tersebut akan terjadi di RT 1/IX, RT 2/IX serta RT 3/IX yang terletak di dalam "mangkuk" potensi longsor (Gambar 5.b). Jumlah kepala keluarga (KK) dan penduduk masing-masing RT tersebut berturutturut adalah sebagai berikut $29 \mathrm{KK}, 183$ jiwa; $10 \mathrm{KK}, 45$ jiwa dan $8 \mathrm{KK}, 38$ jiwa (sumber: papan informasi posko bantuan) (Pusat Studi Kebumian dan Bencana, 2012).

Penetapan Kebijakan Strategi

Setelah mengetahui pengembangan skenario terjadinya bencana, langkah selanjutnya adalah menetapkan kebijakan dan strategi penanganan bencana yang meliputi kebijakan dan strategi. Kebijakan penanganan tanggap darurat, jika bencana tersebut terjadi, dimaksudkan untuk memberikan arahan atau pedoman bagi stakeholders maupun sektor-sektor terkait untuk dapat melaksanakan kegiatan tanggap darurat tersebut. Diperlukan kesepakatan bersama untuk membuat rencana tanggap darurat ini dan hasilnya dijadikan suatu kebi- 
jakan yang sifatnya mengikat. Kebijakan tersebut dapat meliputi penetapan waktu tanggap darurat, layanan pengobatan, dan penyiapan alat dan material.

Sedangkan strategi penanganan tanggap darurat bertujuan untuk melaksanakan kebijakan tersebut dengan efektif dan efisien. Untuk itu diperlukan pembuatan tugas dan tanggung jawab masingmasing sektor sesuai dengan sumberdaya dan kompetensi yang dimilikinya.

Kebijakan dalam mengantisipasi ancaman tanah longsor adalah sebagai berikut (Pusat Studi Kebumian dan Bencana, 2012):

a. Mengkoordinasikan kegiatan penanganan tanah longsor secara integratif yang berbasis masyarakat.

b. Rehabilitasi dan revitalisasi sarana prasarana terkait dengan kebutuhan pelayanan minimal.

c. Penanganan masalah sosial di tempat evakuasi secara cepat, tepat, dan terpadu.

d. Pemenuhan pelayanan sosial dasar secara terpadu dan optimal bagi semua korban.

e. Penyediaan informasi penanggulangan bencana yang akurat.

f. Mengkoordinasikan dan memobilisasi kelompok strategis Penanggulangan Bencana dalam operasional tanggap darurat.

g. Penanganan/pemulihan darurat pada saat tanggap darurat.

h. Penanganan gawat darurat medik terhadap korban.

i. Penanganan kesehatan untuk mengurangi risiko munculnya penyakit.

j. Pengelolaan bantuan secara optimal. k. Dalam hal kejadian bencana yang mengakibatkan tidak berjalannya fungsi pelayanan kesehatan setempat, kendali operasional diambil alih secara berjenjang ke tingkat yang lebih tinggi.

1. Perlu dilakukan monitoring dan evaluasi.

$\mathrm{m}$. Pengadaan tempat pengungsian yang memadai.

Strategi dalam mengantisipasi ancaman tanah longsor adalah sebagai berikut:

a. Merealisasikan koordinasi kegiatan penanganan bilamana terjadi tanah longsor yang berbasis masyarakat.

b. Menyediakan/memfasilitasi sarpras terkait dengan kebutuhan pelayanan minimal.

c. Memerintahkan seluruh dinas instansi lembaga masyarakat untuk mengerahkan semua sumber daya dengan mempergunakan prasarana dan sarana yang dimiliki masing-masing sektor.

d. Menyediakan sarana mobilitas pengungsi antara lain; angkutan barang, angkutan pengungsi, ambulance, medis dan para medis dan obat-obatan dalam upaya memberiakan perlindungan dan pelayanan kesehatan kepada para penggungsi.

e. Melakukan pengawasan dan pengendalian, monitoring serta evaluasi terhadap sektor-sektor operasional di lapangan.

f. Menempatkan kelompok-kelompok strategis sesuai bidang masing-masing ke lokasi bencana dan segera melakukan tindakan sesuai tugasnya yang sudah tersusun pada SOP.

g. Menempatkan sarana untuk mendukung kegiatan pada point diatas. 
h. Melaksanakan pemulihan pada daerah yang terjadi kerusakan berdasarkan prioritas.

i. Setiap korban akibat bencana perlu mendapatkan pelayanan sesegera mungkin secara maksimal dan manusiawi.

j. Prioritas awal selama masa tanggap darurat adalah penanganan gawat darurat medik terhadap korban luka dan identifikasi korban mati di sarana kesehatan.

k. Prioritas berikutnya adalah kegiatan kesehatan untuk mengurangi risiko munculnya bencana lanjutan, di wilayah yg terkena bencana dan di lokasi pengungsian.

1. Managemen bantuan dari penerimaan sampai pendistribusian sehingga bantuan tersebut aman bagi korban.

m. Bantuan teknis medis maupun peralatan sesuai dengan kebutuhan dan sarana yang ada didaerah, bila tidak mencukupi akan diberikan bantuan oleh instansi diatasnya.

n. Monitoring evaluasi setiap saat baik rutin maupun insidentil dengan tujuan perbaikan pelayanan secepatnya.

Analisis Kesenjangan

Dalam melakukan analisis kesenjangan dapat dibagi dalam beberapa sektor, diantaranya sektor manajemen dan koordinasi, sektor evakuasi, sektor logistik (pangan dan non-pangan), sektor kesehatan, sektor perhubungan dan sarana/prasarana.

Untuk Sektor Manajemen dan Koordinasi pada saat kejadian, upaya-upaya yang harus dilakukan, antara lain (Pusat Studi Kebumian dan Bencana, 2012):
1. Sebelum terjadi longsor BPBD dan BMKG setempat melakukan pemantauan cuaca dan kondisi wilayah potensi longsor tersebut

2. Apabila terjadi longsor, masyarakat melaporkan kepada aparat dusun/ desa/kecamatan. Aparat pemerintah tersebut langsung melaporkan kejadian kepada BPBD (atau kantor polisi terdekat, jika melalui polisi harap diteruskan ke kantor BPBD atau Polres setempat), dapat melalui pesan singkat (sms) atau telepon kepada kontak person nomor darurat. BPBD melaporkan kepada Bupati Pacitan dan selanjutnya mengkoordinasikan dengan pihak-pihak terkait. Selaku kepala daerah, Bupati mengkoordinir penanggulangan bencana tersebut. Selama proses tersebut, Bupati Pacitan memberi laporan kepada BPBD Provinsi Jatim dan Gubernur Jatim.

3. Semua instansi yang terkait dengan penanggulangan bencana siap di Posko yang sudah ditentukan yaitu di lokasi yang agak jauh dari lokasi longsor dan yang diperkirakan aman dari longsor.

4. Incident Commander (IC) dalam hal ini Bupati Pacitan, atau yang ditunjuk, segera menentukan, menginstruksikan tindakan-tindakan, langkah-langkah yang harus dilaksanakan dalam rangka penanganan darurat.

Stakeholder yang dapat dilibatkan dalam Sektor ini adalah Bupati Pacitan BPBD Pacitan, BMKG Pacitan, Polres, TNI. Juga dapat melibatkan ORARI, RAPI, Dishub kominfo untuk menerima dan menyampaikan informasi, serta masyarakat. Selain itu dapat melibatkan Dinsosnakertrans, PMI, SAR Polres, 
SAR Kodim, Brigade Penolong (Pramu$\mathrm{ka)}$.

Kebutuhan sektor ini diantaranya adalah alat komunikasi seperti telepon, radio komunikasi, sound system, handy talkie. Alat dokumentasi seperti kamera dan handycam, alat transportasi akses ke lokasi, serta tenda darurat dan kelengkapannya untuk lokasi koordinasi di lokasi setempat. Dari hasi FGD dapat disimpulkan bahwa kondisi kebutuhan untuk Sektor Manajemen dan Koordinasi dapat dipenuhi semua meskipun ada beberapa item jumlahnya terbatas.

Untuk Sektor Evakuasi (Penyelamatan dan Perlindungan, SAR) pada saat kejadian, upaya-upaya yang harus dilakukan, antara lain: Pertolongan dan perlindungan bagi yang masih hidup, mencegah agar tidak berkembangnya jatuh korban, evakuasi mayat/korban, penyelamatan dan perlindungan, SAR bagi masyarakat/korban hidup/mati, inventarisasi masyarakat/korban bencana, penanganan secara maksimal masyarakat/korban bencana. Pada sektor ini ketersediaan seperti kantung mayat dan alat evakuasi lainnya (misalkan cangkul, dll) masih mengalami kekurangan yang cukup banyak.

Untuk Sektor Logistik (Pangan dan Non-Pangan) pada saat kejadian, upayaupaya yang harus dilakukan, antara lain (Pusat Studi Kebumian dan Bencana, 2012) langkah-langkah penyelamatan dan pelayanan sosial berupa pemenuhan kebutuhan dasar bagi para korban hidup dan petugas lapangan dalam bentuk pendirian shelter (pengungsian), pemberian bantuan seperti sandang, pangan, dan papan, sebagai upaya tanggap darurat tahap pertama selama 15 hari. Sasaran-sasaran pada sektor ini antara lain terlayaninya semua kebutuhan dasar pengungsi, mulai dari balita sampai kepada orang tua dan petugas selama masa tanggap darurat, tersedianya tempat penampungan yang layak dan terlaksananya penerimaan, penyortiran dan pendistribusian logistik sesuai dengan sasaran. Instansi yang dapat berperan di sektor ini antara lain Dinsosnakertrans dan BPBD, dan dapat dibantu oleh Tagana. Dari segi kesenjangan kebutuhan dan sumberdaya diperkirakan hal dasar yang belum dapat tercukupi adalah kebutuhan bahan pangan (beras, air bersih, lauk-pauk, dll), sedangkan yang telah mampu dipenuhi adalah kelengkapan dapur umum dan kelengkapan posko.

Untuk Sektor Kesehatan pada saat kejadian, upaya-upaya yang harus dilakukan, antara lain terlaksananya pelayanan kesehatan bagi pengungsi, terlaksananya tindakan medis bagi korban luka, terlaksananya rujukan kesehatan yang optimal, dan mengurangi resiko terjadinya penularan penyakit terutama pada lokasi pengungsian. Sedangkan kondisi pengungsi yang memungkinkan adalah bila terjadi longsor maka kemungkinan yang terjadi adalah terdapat penduduk yang menderita luka-luka dan mungkin patah tulang akibat tertimpa reruntuhan bangunan, ada yang tertimbun dan diperkirakan tidak ada fasilitas kesehatan yang terdampak pada bencana amblesan ini. 
Instansi yang dapat dilibatkan dalam sektor ini adalah Dinas Kesehatan, Palang Merah Indonesia, dan BPBD. Untuk tenaga medis Kabupaten Pacitan tidak mengalami kekurangan, baik dokter maupun perawat. Selain itu, Kabupaten Pacitan juga memiliki dokter spesialis bedah dan spesialis anastesi, psikolog, ahli gizi, apoteker, dan juga memiliki kelengkapan kesehatan yang memadai juga termasuk Disaster Victim Identification (DVI).

Sektor Perhubungan dan Sarana/Prasarana bertugas untuk melancarkan tim evakuasi untuk melakukan pertolongan gawat darurat di lokasi kejadian dan melancarkan proses kedatangan alat berat sebagai peralatan utama evakuasi. Sektor ini merupakan kerjasama instansi bidang pekerjaan umum, dinas perhubungan, polres, dan BPBD. Ketersediaan alat berat sampai dengan saat FGD dilaksanakan adalah grader dan dump truck, sedangkan ekscavator belum tersedia.

\section{Simpulan}

Berdasarkan survei dan wawancara yang dilakukan pada saat terjadinya longsor di awal tahun 2011, masyarakat telah memahami tanda-tanda utama longsor, diantaranya hujan yang terjadi terus-menerus dalam beberapa hari. Saat itu terlihat, masyarakat secara sadar telah mengungsi di tempat yang dirasa aman, hal tersebut tampak dari dibongkarnya beberapa rumah warga yang berpotensi akan tertimpa longsor. Inisiatif tersebut menunjukkan bahwa masyarakat Dusun Sono sangat mem- ahami dampak yang ditumbulkan akibat longsor sehingga dengan kesadaran membongkar rumah untuk pindah ke tempat yang aman.

Berdasarkan rencana kontijensi yang telah disusun tersebut (berupa Dokumen Rencana Kontijensi), maka berbagai stakeholder di Kabupaten Pacitan dapat dikelompokkan dalam lima sektor yang bergerak berdasarkan instruksi Bupati Pacitan atau yang ditunjuk, dengan koordinasi utama ada pada sektor manajemen dan koordinasi. Selain itu, ada beberapa kesenjangan antara kebutuhan dan ketersediaan sumber daya seperti kurangnya katong mayat, alat evakuasi, dll. Sedangkan kebutuhan yang telah melebihi kebutuhan adalah terkait dengan jumlah tenaga medis.

\section{Daftar Pustaka}

Priyono. (2008). Analisis Morfometri dan Morfostruktur lereng Kejadian Longsor di Kecamatan Banjarmangu, Kabupaten Banjarnegara. Forum Geografi, 22 (1). pp. 72-84. ISSN 0852-0682

Pusat Studi Kebumian dan Bencana. (2012). Rencana Kontijensi Bencana Tanah Longsor di Tulakan, Kabupaten Pacitan. BPBD JatimPSKB ITS. Surabaya.

Suryolelono K.B., (2002). Bencana Alam Tanah Longsor Perspektif Ilmu Geologi Teknik. Pidato Pengukuhan Jabatan Guru Besar.

Sugeng Triutomo, B. Wisnu Widjaja, R. Sugiharto, Siswanto B.P., Yohanes Kristanto. (2011). Panduan 
Perencanaan Kontijensi Menghadapi Bencana, Ed. 2. Badan Nasional Penanggulangan Bencana. ISBN 978-979-18441-3-0. Jakarta.

Tatas, Machsus, Amien Widodo. (2011). Studi Investigasi Longsor di Desa Kalikuning, Kecamatan Tulakan, Kabupaten Pacitan. Jurnal Aplikasi ISSN.1907-753X.

Surabaya 